\title{
The silver bullet and the golden goose
}

\author{
A healthy profit.
}

\begin{abstract}
Norman Spinrad
No, I'm not a Communist, but I'm not a capitalist either, not having the capital to finish the work any further myself, and that's the only reason I'm on my way to Cuba. If I can get there and convince the Cubans, the world won't care that they're Communists when they begin distributing the cure for cancer. But even paranoiacs can have real enemies, and if mine manage to stop me, maybe this missive, tossed into the media ocean like a desperate message in multiple bottles, will at least tell the world what is being suppressed.

And why.

Was I hopelessly naive?

That's what I was told one way or another by every major drug company I approached with the research that would surely lead to the cure for cancer. Not just for one specific cancer but for whole clades of malignancies. Not just another chemotherapy drug whose efficacy is measured in mere months of extended lifespan. Not something patients
\end{abstract} must take for the rest of their lives, like the AIDS cocktails, in order for those lives to continue.

The long-sought — or at least so I naively believed - silver bullet. The de-selfing of cancer cells and cancer cells alone, exposing every last one of them to destruction by any reasonably healthy human immune system without negative effects on any normal cells at all.

How much dare I reveal here not knowing who will read it?

I can tell you, whoever you may be, that $m y$ research has not been anything like that of the major drug companies and corporate laboratories upon which billions of dollars have been squandered since Richard Nixon declared the "War on Cancer" - a forever war, like the one on terrorism, that has produced many chemotherapy drugs that can hold back cancers, some for as long as they are taken, but damn little in the way of permanent cures.

I can tell you that my research has been based on the long-known fact that cancer cells arise and are destroyed by everyone's immune system all the time, and that if this process were perfected, cancer as a deadly

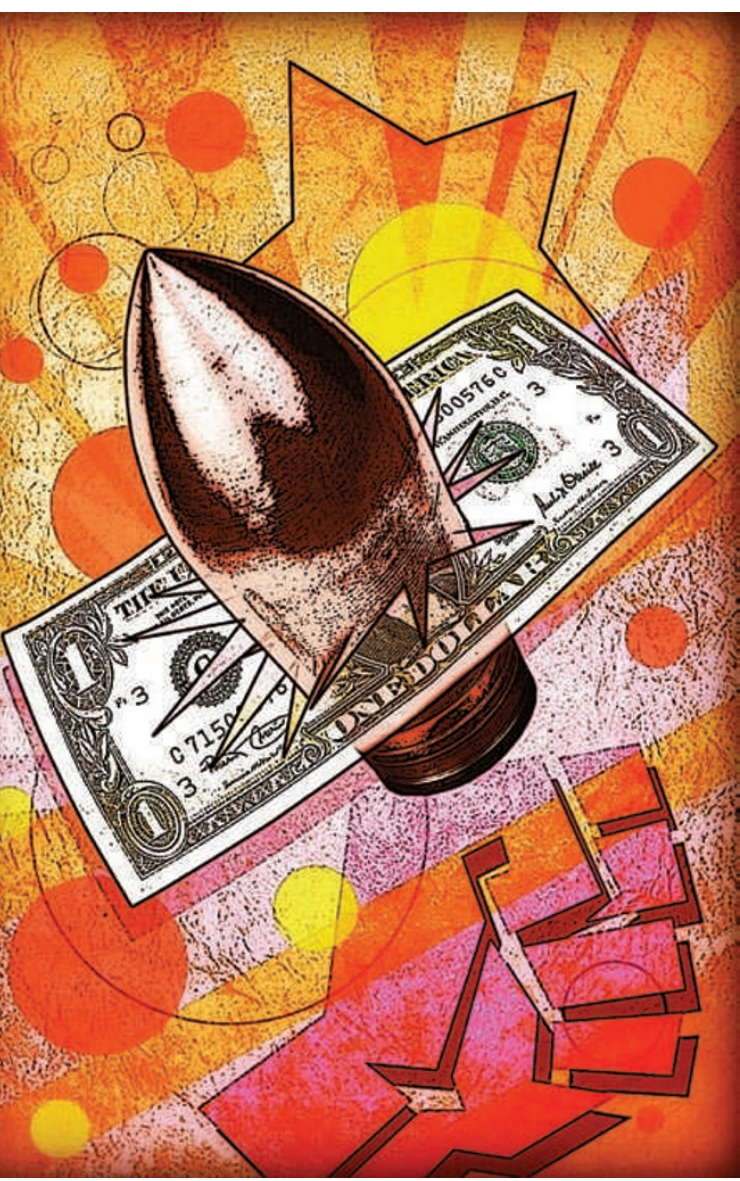

populations I had discovered and of their total biome surroundings on an interactive molecular level; synthesis of candidate combinations and their large-scale testing on neutral populations.

But the companies could well afford it, it was just the sort of dogged process that produced their streams of chemotherapy drugs, and out the other end this time would come the broad-spectrum cure for most if not all cancer. I'd simply tell all of them and let them compete to produce the silver bullet.

Hopelessly naive! So I was told, repeatedly.

"Don't you watch television? Have you ever seen an ad for any drug that cured anything? It costs scores of millions to get any new drug out on the market, and that means we've got to keep selling it until the patent runs out. And chemotherapy drugs for cancer that the customers have to take indefinitely to stay alive are the profit centre that keeps this industry in the black. Your silver bullet cure would pull the rug out from our major profit centre and you expect us disease would not exist.

I can tell you that I spent a decade and more travelling the globe to seek out small tribal populations where, in fact, it did not exist - in jungles, deserts, obscure little islands. And that I found a dozen of them.

I can't tell you where.

I depleted my finances getting the characteristic genomes of these isolated populations sequenced, only to find to my dismay that they seemed to have nothing relevant in common.

I can tell you that I realized the obvious under the influence of a local psychedelic in a hut in a jungle - if the cause of the absence of cancer in these isolated populations was not genetic, it could only be environmental.

Something common to a dozen isolated biomes, and probably a complex brew of many somethings coming together synergistically. Discover what the mix was, synthesize it and, voila, the silver bullet! It would take the financial and technical resources of a major drug company to do it, as it would require exhaustive studies of the to pay for killing our own golden goose?

"What are you, some kind of Communist?"

No, I'm not, but the Cuban government still is, isn't it? Or, at least, their health-care system and their drug industry is government financed, and so their economic selfinterest is in cutting health-care cost, not inflating it to maximize profit.

That's why I'm on my way to Cuba.

That's why I can't risk revealing the location of the cancer-free populations I've discovered. Do I want to find out how far those whose economic self-interest is the opposite direction will go to protect their golden goose from my silver bullet?

I'm a scientist, neither a capitalist nor a Communist.

But that naive I no longer am.

Norman Spinrad's latest novel is $\mathrm{He}$ Walked Among Us. He very recently spent three weeks in hospital being treated for stomach cancer, where he wrote an Internet diary on the experience in real-time. Now at home recovering well and back to work, but still receiving chemotherapy. 